\title{
Reform and Design of Dance Teaching for Preschool Education Majors in Higher Vocational College
}

\author{
Lu Chen \\ Qingdao Technical \& Vocational College (China Qingdao 266555)
}

\begin{abstract}
Keywords: Higher vocational college; Preschool education; Dance teaching; Reform; Design
\end{abstract}
\begin{abstract}
This article analyzes the current situation and problems of preschool education dance teaching in higher vocational colleges, and it elaborates the methods and ideas of reform and design of preschool education dance teaching from different aspects, and hopes that it can be used to improve the teaching level of preschool education.

With the constant development and progress of our society, the entire Chinese people have also paid increasing attention to the issue of education, especially the early childhood education, which even affects the attention of the whole society. The society has higher and higher requirements for early childhood education and higher and higher requirements for early childhood education teachers, and how to improve the level of early childhood teachers has become the most important concern of the entire society. Dance is one of the essential subjects for the education and teaching of preschool education in higher vocational college. Through systematic study and training, students can master a variety of dance methods and master the techniques of choreography, and enable to master independent performances during the learning process. However, at present, there are still many problems in the dance teaching of preschool education majors in our country. There is an urgent need for a teaching reform. Based on the existing problems, we have designed some targeted reform ideas and methods and hope to provide help for teachers and students.
\end{abstract}

\section{Part One Problems in Dance Teaching of Preschool Education in Higher Vocational College}

At present, with the change and progress of people's concepts, people are paying more and more attention to the comprehensive quality of preschool education students. A single skill can no longer meet the expectations of the society, which means schools must train comprehensive talents.

\section{Course Objectives are not Clear Enough}

Vocational preschool education dance courses pay much emphasis on knowledge and technology professor, and do not have enough emphasis on ability and accomplishment. More than $70 \%$ of students do not try or basically did not choreograph their teaching achievements in terms of their ability to dance. There is even less experience in this field. Most of the students can accurately identify the staves and scores, but only about $15 \%$ of them are actually implemented. It can be clearly seen that although students have learned the basics, but they have not formed the ability and literacy.

\section{Course Content are not Reasonable}

The importance and special function of dance courses for the growth of young children have been acknowledged by the majority of early childhood educators and scholars. However, the generally low musical literacy and dance literacy of kindergarten teachers are the key factors that restrict the quality of children's dance teaching. Firstly, preschool education demands more and more preschool teachers. However, the curriculum is a fragmented discipline-centered teaching method. Single skill and single knowledge have always been the focus of teaching, while the teachers neglect students' ability in many aspects in literacy training. Secondly, since all higher vocational colleges do not attach importance to the effective integration of subject knowledge which results in students are not capable of comprehensive utilization of the learned knowledge and skills, and students are faced with the parents and the community after graduation requirements that they not only to sing and dance, but also to speak, write, arrange and simple creation. Therefore, the current curriculum content cannot meet the expectations of the society and parents, and it is even more difficult to meet the needs of early childhood education reform. 


\section{Teaching focuses are not Enough Scientific and Rational}

There is a serious misunderstanding in the current vocational school, which is to equate dance teaching with music learning. Currently, the preschool education are offered by vocational courses including instrumental music, vocal music, dance and so on. However, in actual teaching and learning, many courses have the phenomenon of over-emphasis on technology and neglecting art. Since preschool education's students are only children, and the nature of work is education. Therefore, they should not spend too much time on professional skills. Instead, they should enlighten students and make them aware of various kinds of dance and understanding, while cultivating students' interest in dancing. This requirement determines that professional performers and dancers are not necessarily able to teach young children well. With the progress of modern information technology, the channels for young children to gain access to information have also increased greatly. Their thirst for knowledge has also greatly expanded, and this puts forward higher and higher requirements for the knowledge and ability of preschool teachers. Therefore, it is right to place much emphasis on the importance of the comprehensive.

\section{Part Two Reform And Design Of Dancing Teaching For Preschool Education In Higher Vocational College}

The reform and design of preschool education dance teaching should seize the social needs and firmly grasp the growth needs of young children. We should start with the following aspects:

\section{Identifying the Course Objectives}

The first is the skill goal. Through the teaching and training of dance subjects, the comprehensive literacy and artistic accomplishment of higher vocational students should be enhanced so that they can master the basic dance theory and dance skills for preschool education and have qualified abilities of playing, jumping and singing. A variety of activities should be provided with accompaniment, organization, assistance, arranger, choreography and so on, and we should lay a solid foundation for students to develop their expertise followed by the theoretical goal. Through a comprehensive and rigorous theoretical study, vocational students should be able to comprehensively apply the learned theoretical knowledge of music and dance, integrate knowledge and skills, and theoretically reserve children to conduct various musical and dance education activities scientifically and skill reserve. And this will enable vocational students with the ability to create a living environment through the creation of a variety of music and dance environment to develop children's intelligence, ability, teamwork. At the same time, vocational students should have organizational planning, observation and analysis and the ability to coordinate child care activities, and be able to carry out various activities for the characteristics of students. At the same time, kindergarten teachers must have the ability to continue learning, keep learning the latest scientific research and guide their own teaching.

\section{Choosing Teaching Content}

According to the teaching objectives of preschool education in higher vocational colleges, we should select appropriate teaching contents in dance courses so that students can integrate dance contents scientifically and reasonably, and finally finish the teaching content. The choice of teaching contents of dance courses should be based on the basis of dance, dance skills and choreography. The three stages are basic courses, folk dance classes and comprehensive classes. Through these three stages of learning and training, it can achieve the desired results of the course. The first is a basic lesson. The main content of the basic course is classical dance. Through the study of classical dance, the charm and basic skills of vocational students are trained, and the body language is liberated and regulated, and the rigid body language that is not suitable for dance is freed up. Students are initially provided with certain professional qualifications, At the same time, we should also have a complete understanding of human muscles, bones and so on, and understand how to train and how to protect various parts of the body, and lay a solid foundation for future children's dance courses. The second is ethnic dance lessons. China is a multinational country, and each ethnic dance is an important source of traditional dance in our country. Through the study of folk dance, it is possible to enhance the artistic accomplishment and comprehensive 
accomplishment of higher vocational students while enhancing the performance level and accumulating the students' future choreography adequate material. At present, the main source of dance courses for preschool education majors is the dance of ethnic minorities such as Mongolian, Tibetan and so on. It should be from simple to complex and from easy to difficult, and allow students to gradually master complex dances. The third is comprehensive class. When you finish the first two classes, you need to integrate what you have learned to form an integrated ability. This part of the teaching content includes the basic dance theory, basic skills, dance creation and choreography, basic theory of early childhood dance, music and dance appreciation, and it can highlight the professional highlighting the childhood at this stage.

\section{Choosing the Appropriate Teaching Method}

Dance is an art that shows the beauty of the body and the beauty of strength. There is an old saying that it is very appropriate and can only be interpreted unspeakably. This teaching of oral education requires a high degree of comprehensive ability of teachers. The teaching of dance requires that students must be able to make dance movements in a regular and accurate manner. At the same time, students must be able to understand and read. Students will imitate the teacher's actions to learn and understand, and under the guidance of the teacher to learn the essence of dance, so the appropriate teaching methods is particularly important. The first is the basic lesson. In this class, students should pay attention to the training of a single action, such as training of hands and feet, limbs, eyes, head and breath, and cultivate the feeling of body and dance learned. At this stage, teachers are mainly used to model students' imitations. Students must be allowed to act and they must know how to act correctly. After the completion of each new lesson, students should be dared to demonstrate. Teachers should constantly correct the students' movements so that students can master the essentials of movement in continuous practice. The second is the ethnic dance lessons. This is the focus of learning content that should be based on the students in different situations with using different teaching methods. Through the study and training of ethnic dance, students should master the style and rhythm of each typical national dance. We must broaden students' horizons and knowledge so that students can accumulate material extensively and continuously improve their appreciation and performance ability. Through the influence of these traditional cultures, students are encouraged to set up the correct concept of "three perspectives" so that they can generate pride and identity and inspire their initiative in learning. The third is the comprehensive class. Improving the students' coordination, responsiveness, body flexibility and other comprehensive literacy, and students gradually have the ability to dance choreographer. First of all, letting the students improve dance movements and queues in a cooperative manner after they have mastered the dance movements. Then letting the students master the training methods and some key points for the choreography of young children's choreography. Finally, under the unified guidance of the teachers, students are allowed to compile their own dances.

\section{Conclusion}

To sum up, dance is a necessary preschool education course. Higher vocational college's teachers must have a clear understanding of the problems in the current dance curriculum, and make concerted reforms to improve the quality of teaching with designing dance courses that are more suitable for higher vocational students and provide parents with confidence, and allow students to grow up healthily and happily. And the outstanding preschool teachers can make contributions to society.

\section{References}

[1] Qiong Xie. Discussion on the reform of preschool education dance teaching in higher vocational colleges[J].Road to Success,2009(34):28-29.

[2] Yali Xiong, Huiju Chen, Jingyi Qi. Exploration on teaching reform of preschool education in higher vocational colleges_-Taking Lijiang Teachers College for example[J].Chinese Science and Education Innovation Guide,2011(17):182-183. 